\title{
Against the odds: The evolution of the European naval shipbuilding industry
}

\section{Renaud Bellais}

Renaud Bellais is Associate Researcher at Ecole Nationale Supérieure de Techniques Avancées Bretagne (ENSTA Bretagne), Brest, France. He may be reached at renaud.bellais@airbus.com.

\section{Abstract}

Despite a low volume of production at national levels, the European naval industry remains quite fragmented 25 years after the end of the cold war. Contrary to what might be expected from an industrial or budgetary perspective, neither cross-border consolidation nor cooperative programs have resulted in European restructuring. The sovereign nature of shipyards has led to the promotion of a domestically-centered industry transformation. Again, contrary to what might be expected, this appears to be a potentially sustainable approach due to the long-term relationship between navies and their domestic industrial partners. Even so, one can question the sustainability of the current economic model, reliant as it is on export contracts and insufficient margins to manoeuver.

$\mathrm{W}$ hile other arms production sectors have engaged in a consolidation process, even if on a limited scale, the setup of the European military naval industry is quite similar today to what it was at the end of the cold war. Of all arms sectors, it is certainly the one for which the emergence of a European-wide defense technological and industrial base appears as a distant future option. The lack of consolidation appears paradoxical, however, as shipyards have faced decreasing military spending (as have many other defense industries). Shipbuilding requires the investment of large sunk costs - both in development and production. With production series of very limited numbers, this drives up unit costs.

Moreover, connections between military and commercial shipyards have been increasingly limited since the beginning of the 1990s, making development of dual-use platforms less likely. Defense-related companies tend to specialize in military naval systems as strong competitors, first from Japan in the 1970s, and since then from South Korea and China, have destroyed most commercial ship production in Europe. This is the primary reason why, sooner or later, a shipyard consolidation process was expected to adjust Europe's industrial capabilities to a lower scale of production. ${ }^{1}$

Increasing the effectiveness of Europe's naval industry is a requirement to preserve technological and industrial assets that remain important to achieve defense and security goals. Naval systems were not favored after the end of the cold war, especially since most military operations did not take place in high seas, but they remain essential to project forces, implement security missions, and support operations away from the homeland. And new threats have emerged that require naval capabilities, ranging from piracy to terrorism, illegal migration, and tensions in the South China Sea.
Even as the idea of a "Naval Airbus" has been proposed from time to time, the consolidation of the industry has been quite limited over the past three decades. The questions nonetheless stand: Is consolidation truly an issue, let alone a necessity, for the European naval industry? And can European naval consolidation be achieved with regard to states' specific interests, e.g., their strategic autonomy, and companies' own industrial stakes and long-term survival? ${ }^{2}$

Focusing on producers of large naval platforms - aircraft carriers, frigates, and submarines produced by the six largest of Europe's shipyards (BAE Systems, DCNS, ThyssenKrupp, Fincantieri, Navantia, and Saab) - this article first examines the historical evolution and industrial heterogeneity of the industry, detailing reasons why no trans-European leader has emerged over the past few decades. Another section analyses the extent to which the model of nation-centric naval industries addresses expectations of domestic customers and thus maintains this non-consolidation. Industry options and risks are discussed.

\section{A nation-centric industry}

In October 2016, the Chief Executive of the European Defense Agency (EDA), Jorge Domecq, called for more naval program cooperation in Europe, notably for next generation platforms. Indeed, despite limited production, each major arms-producing country keeps its own naval shipyard. Which factors explain this lack of Europeanization? Does this status quo jeopardize preservation of Europe's naval competencies?

\section{Features of the European naval industry}

The global market for naval systems is estimated at around US $\$ 40$ billion. American companies dominate the market with a total turnover reaching USD12 billion but are completely 
Table 1: Main actors in the European naval industry (2015)

$\begin{array}{lccc}\begin{array}{l}\text { Company } \\ \text { BAE }\end{array} & \text { Country } & \begin{array}{c}\text { Naval turnover } \\ \text { (EUR millions) }\end{array} & \begin{array}{c}\text { Naval } \\ \text { employees }\end{array} \\ \text { DCNS } & \text { U.K. } & 6,900 & 14,000 \\ \text { TKMS } & \text { France } & 3,040 & 12,950 \\ \text { Fincantieri } & \text { Italy } & 1,060 & \sim 5,000 \\ \text { Navantia } & \text { Spain } & 705 & 5,500 \\ \text { Saab } & \text { Sweden } & 460 & 850 \\ \text { Kockums } & & & \end{array}$

Source: Annual company reports and websites. Note: EUR are at average European Central Bank exchange rates for 2015.

centered on the needs of the United States. The U.S. market is sheltered from international competition and, simultaneously, American companies work almost exclusively for the Pentagon. Naval shipyards in China and Russia claim between USD3 to 4 billion, and they, too, work mainly for their domestic customers, sheltered from external competition. ${ }^{3}$

The European markets are worth around USD10 billion. In addition, European companies derive a large share of their turnover from export markets. (They generally make up about half of their sales but the ratio of domestic to international revenues varies widely from year to year.) While there are tens of industrial actors, the European naval industry is dominated by six big companies (see Table 1). The sector constitutes about 25 percent of Europe's defense industrial base and features very complex, sophisticated, high-tech products. The industry has developed all competencies required to design, integrate, and produce the whole range of naval ships and almost the totality of its core systems and components. The major companies are system integrators, and the old image of shipbuilders as mere assemblers of steel blocks is outdated.

However, the European naval sector is characterized by overcapacity, fragmentation, and redundant structures. Each arms-producing country with naval ambitions has its own national champion, the main reason why there exist a large number of ongoing programs for quite similar platforms. In 2009, then- EDA Chief Executive Alexander Weis stated: "For each U.S. naval system, Europe has 7.2 systems. Europe is still able to afford 11 different frigates, and 7 different diesel submarines. There are currently 25 naval prime contractors
This article examines the evolution and current state of affairs in the European military shipbuilding industry. It finds that while the "national champions"-based approach of the major European naval powers works reasonably well in the current environment, financial dangers loom on the horizon that could yet force substantial pan-European consolidation of the industry.

across Europe, many of them encompassing more than one shipyard." His successor, Jorge Domecq, made a similar observation in 2016: "European navies operate 20 different types of frigate, four different types of aircraft carrier, and multiple types of support ships and MCM Vessels." Despite a limited market, arms-producing countries reserve major naval procurement contracts for their domestic shipyards. This lack of industrial consolidation beyond national borders puts the survival of the industry at risk due to the very limited and irregular workload schedule. ${ }^{4}$

As will be shown, this does not mean that consolidation never occurred. With the end of the cold war, national consolidation was widely seen as a precondition for eventual transnational restructuring. But the domestic consolidation phase was not followed by a Europe-wide one.

Limited, and reversible, consolidation at the European scale One writer noted in 2004, that "despite the encouraging noises made at the Euronaval show here this week about the consolidation of Europe's naval shipbuilding industry, the fact remains that the prospect of a pan-European naval group is still a long way off, and may in fact never materialize." This still appears to be the case today. In the years following the end of the cold war, one could perceive a wish to consolidate strategic industrial assets to overcome the fall of military spending. However, except for one example - later reversed - a Europewide transformation of the naval industry was not achieved. ${ }^{5}$

The idea of creating a "Naval Airbus" has been promoted for several decades. Airbus, in the aeronautics industry, was an answer to a deep crisis of the civilian aeronautical industry in the late 1960s. France, Germany, and the United Kingdom each had domestic aircraft industries that were too fragmented and small to face American competition. The only solution was to consolidate industrial assets and create a European company, able to invest and innovate to regain international leadership. To a large extent, the European naval industry faced the same challenges in the early 1990s. Yet no major consolidation happened. Conflicting interests prevented companies from consolidating at the European level. For one thing, consolidation would mean that each company would lose essential assets for future production and national programs. 
Additionally, a significant part of the European naval industry was composed of state-owned companies (until recently). This was not deemed compatible with private companies' interests. For instance, a merger between DCNS and ThyssenKrupp was often seen as a major possible move to restructure naval assets at the relevant scale to secure the future of Europe's naval industrial base. But ThyssenKrupp has always considered the state ownership of DCNS as a "no go" situation because of a fear of political interference with its own strategic decisions. Indeed history shows that all too often state ownership has resulted in political rather than industrial decisions, like the preservation of inefficient sites to meet local political concerns unaligned with, or even contradictory to, sound business strategy. ${ }^{6}$

Moreover, the only significant cross-border merger ended as a failure. In 1999, the German shipyard HDW bought its Swedish counterpart Kockums, one of its main competitors in the submarine market. It also bought Hellenic Shipyards in 2002. In 2005, ThyssenKrupp took over HDW, adding its own naval assets in surface vessels. Unexpectedly, these moves in the direction of the long-awaited industry-wide restructuring did not result in lasting consolidation. Not only did these mergers not result in cross-border specialization, but ThyssenKrupp and Kockums demerged in 2014. The reason was that first HDW's, and then ThyssenKrupp's, strategy was not compatible with the preservation of Swedish submarine capabilities. German decisionmakers would not support the A26 submarine project sponsored by the Swedish Ministry of Defense. In addition, on export markets, ThyssenKrupp promoted German-designed submarines while pushing Kockums to discontinue construction of its large submarines in favor of focusing on the development of small submarines. Perceiving ThyssenKrupp's business strategy as a threat to its strategic autonomy, Sweden decided to grant its next-generation submarine program to Saab (even though Saab had no shipyard). Losing its sole source of Swedish revenue, ThyssenKrupp had no choice but to sell its Swedish assets to Saab (which is how Saab acquired a shipyard). The demerger recreated a purely domestic Swedish naval champion, reversing the hoped-for consolidation at the European level. ${ }^{7}$

\section{Unhappy cooperative programs}

If mergers and acquisitions are an obvious and rapid way for industry consolidation, cooperative programs are a second-best solution. Following the examples of the aeronautics and space sectors, cross-country cooperation might help rationalize the industry. However, naval cooperative programs appear quite unsuccessful in delivering expected homogenous platforms and in pushing ahead with production specialization in Europe.
Confronted with decreasing or low military orders, naval shipyards and states certainly looked for opportunities to cooperate. As mentioned, despite high sunk costs (including $\mathrm{R} \& \mathrm{D})$, the naval sector is characterized by short production series so that unit costs are high. This is why ships and submarines should be natural candidates for cross-country cooperation. Despite this, there are few such programs, and the ones that have taken place have delivered few savings and almost no true cross-border integration. Indeed, recent history is filled with project failures. The most emblematic example is the NFR-90 frigate. Launched in 1979, this ambitious NATO project aimed at developing a unique air-defense frigate for the United States, the United Kingdom, France, Germany, Italy, Spain, and the Netherlands. Aborted in 1989, the project was replaced with the German-Spanish-Dutch Trilateral Frigate program. It resulted in the delivery of three quite different ships: the German F124, the Spanish F100, and the Dutch LCF frigates. France and the United Kingdom ended up in a similar situation when they tried to jointly develop their aircraft carriers, the PA2 and CVF, respectively. Since each country was expected to produce only one or two carriers, it would seem obvious that by joining efforts cost savings could be realized. In 2005, France agreed to pay one-third of the costs of the British CVF design. But it quickly emerged that the British and French Navies were unable to converge on military specifications and, in time, they chose to end their cooperation.

Even when cooperative programs go on, they do not necessarily result in true cross-border industrial consolidation. Beyond the formal appearance of a unique platform, most of the time the resulting ships are quite different from country to country as each requires specific features and promotes domestic technical solutions to guarantee work shares for its own defense industry. The French-Italian FREMM frigate illustrates this outcome. While sharing the same name, the ships' commonalities are so limited that DCNS and Fincantieri compete with each other on export markets.

These unsatisfactory results also reveal one reason why the naval shipbuilding industry remains on a national setup. Such vessels appear extremely customized in response to the specific requests of each Navy. This customization imperative induces huge transaction costs not only with the integrator but also its suppliers (even more than in other cooperative programs such as fighters or military aircraft). Indeed each Navy expects to keep control over key military systems that secure its strategic autonomy, which are developed and produced by domestic companies. Transaction costs thus explode when acquisitions rely on cooperative programs. Although huge, transaction costs can be minimized when the Navy can work with a domestic industrial partner with whom it has established a decades-long 
relation and who perfectly understands its needs, implicit requirements, and specifications. Thus, large transaction costs associated with naval acquisitions favor a reputation-based relationship on a domestic basis. ${ }^{8}$

\section{Consolidation maybe, but only domestically}

In large part because of booming export markets, European manufacturers of military vessels and submarines actually have been doing well in recent years. According to the European defense industry association, known as ASD, European naval turnover has increased from EUR10.2 billion in 2005 to EUR18.7 billion in 2009 and to EUR22.5 billion in 2014. Is Europe-wide consolidation then necessary, especially when considering domestic strategic and nonindustrial criteria? Even if industrial restructuring was required, does the cross-border approach fit this sector well??

\section{Shipyards as a core sovereign capability}

Lack of Europeanization in the naval industry is intrinsically linked to certain features of its industrial assets and naval platforms. Geography, in particular, matters in naval systems, even more so than it does for other defense capabilities.

Apart from production, to provide in-service support (ISS) for their vessels' decades-long life-cycle (vessels can remain in service from 20 years for a surface ship to 50 years for an aircraft carrier, going through regular maintenance, retrofits, and upgrades), navies need access to domestic capacities. Accepting cross-country consolidation would mean the loss of industrial resources to support, retrofit, and modify its platforms. (This need to preserve domestic industrial bases also arises when some capabilities cannot be shared for reasons of sovereignty. The best example is the production and support of deterrence submarines in France and the United Kingdom.) States therefore are reluctant to lose domestic industrial capabilities without which their navies can no longer preserve full autonomy. ISS opens the way for a different industrial model. The naval sector can achieve balance not by leveraging scale economies, as in military aircraft or land systems, but due to a through-life business model that equilibrates production and ISS. BAE Systems and DCNS already prove the feasibility of such a model and its ability to preserve essential competencies on a purely domestic basis. ${ }^{10}$

Arms-producing countries support their domestic naval industry thanks to long-term acquisition plans. For instance, in 2016, the Italian Navy committed to a EUR5.4 billion funding package that secured several programs for Fincantieri, securing long-term production for the shipyard by relying on domestic orders and boosting its export competitiveness. In France, DCNS was awarded a new program for five Belh@rra intermediary frigates in 2016, to be delivered as from 2023 , with a global contract value of EUR3.8 billion. Beyond domestic needs, the French Ministry of Defense expects that DCNS will be able to replicate the export success of the $\mathrm{La}$ Fayette-class frigate of the 1990s, which was acquired by Taiwan, Singapore, and Saudi Arabia. In its 2015 Strategic Defence and Security Review, the U.K. also secured the viability of its naval industry on a domestic basis through the Type 26 frigate program, the future "workhorse of the Royal Navy." Pouring billions of pounds' worth of investment into British shipbuilding, this commitment guarantees hundreds of skilled jobs through 2035.

These acquisition plans are complemented by long-term ISS workloads and constitute a large part of companies' expected revenues. Because of the size of ISS revenues, the share of ISS outsourced by navies, and the exceptional visibility provided to naval shipyards (even compared to other defense industries that provide ISS services), ISS amounts to an original feature of this industry. For instance, in 2008 BAE Systems signed a 15-year partnering agreement with the British Ministry of Defense, which also provided its subsidiary BVT Surface Fleet with leadership of defined future programs.

\section{Consolidation yes, but on domestic grounds}

Saying that the naval sector has not engaged in any restructuring at all would be unfair. The sector did experience successive waves of restructuring in the 1940s, 1960s, and 1970s, notably because of the crisis of merchant shipyards facing tougher competition from East Asia. At the national level, most European countries experienced horizontal consolidation, even well before the 1990s.

In the United Kingdom, there were 42 companies in 1945 (44 shipyards). This reduced to 14 companies (17 shipyards) in 1960 , and then 2 companies (4 shipyards) in 2000. In 2008, BAE Systems and VT Group merged to form a joint venture company, BVT Surface Fleet. In Spain, Astilleros Españoles had been created in 1967 by merging the Basque shipyards of Euskalduna, La Naval de Sestao, and Astilleros de Cádiz. When this entity was merged in 2000 with the public naval shipyards, Empresa Nacional Bazán, to form IZAR (rebranded Navantia in 2005), domestic consolidation was achieved. Similar moves were implemented in other European countries. In Italy, from the 1950s to the 1990s, Fincantieri consolidated all naval shipyards. In Germany, ThyssenKrupp's merge with HDW in 2005 already has been mentioned. In France, while most naval shipyards were state-owned, DCNS rationalized its assets since the 1970s to reduce shipyard numbers and to specialize the remaining ones. And in the Netherlands, Damen Shipyards acquired Royal Schelde in 2001. ${ }^{11}$ 
Shipyard mergers might not be the most relevant option to support the naval industry, however. In fact, European naval shipyards are more likely to cooperate on subsystems, the technological "bricks". This is notably the case for submarine anaerobic propulsion systems between Italian and German companies. Spanish and Norwegian shipyards have cooperated to develop their respective frigates. And in 2015, it was revealed that "DCNS and Fincantieri of Italy [had] agreed on a 'road map' to discuss potential cooperation on further work on the multimission frigate, developing technology and equipment while seeking common benefits."12

Beyond horizontal consolidation, some degree of vertical integration has occurred among the largest naval countries in Europe. This is a recent trend and reflects the displacement of the center of gravity of naval platforms from shipbuilding (hulls) to system integration and embedded systems. To an extent, electronics and weapon systems matter more today than the hull that carries them. It is not surprising that the core of mergers and acquisitions lies in the shipyards and electronics companies of the largest arms-producing countries. Vertical integration took place mostly at the national level, again with the objective to better address the expectations of domestic customers.

In Germany, EADS (now Airbus) and ThyssenKrupp acquired the German naval and electronics specialist Atlas Electronik in 2007 from BAE Systems. This takeover helped create a vertically-integrated naval leader, ThyssenKrupp Marine Systems. In France, the French government tied up DCNS and Thales as the most relevant consolidation for a viable and competitive naval sector. The previously mentioned acquisition of Kockums' shipyard by electronics company Saab led to a similar arrangement under the auspices of the Swedish state. And in the United Kingdom, even if the merger between British Aerospace and Marconi in 1999 was not primarily motivated by naval considerations, in the end it did gather the worlds of defense electronics and naval shipyards within the new company, BAE Systems, through a truly vertical integration.

These examples of vertical integration improved the effectiveness of the naval industry by reducing transaction costs and by nurturing innovation in line with the changes in navies' capability expectations. They strengthened the sector's viability while maintaining a domestically-centered approach that is compatible with the requirements of national strategic autonomy. But this sort of consolidation can be a problem in the longer term as the various national champions in Europe are now quite similar to each other and may seriously hamper future cross-border horizontal consolidation at the European level. Today, any cross-border consolidation would provide few synergies and complementarities and would require that participating companies (and countries) sacrifice part of their domestic assets and competencies.

\section{Exports as a condition for viability?}

Partnership between navies and their domestic suppliers as well as horizontal and vertical integration have contributed to the domestic viability of Europe's naval industries. Yet these developments are insufficient. Domestic orders alone are not enough, in part because of the cyclical nature of domestic orders and production, in part because of declining European naval budgets. Therefore, the industry's reliance on export orders has not only increased but become essential. European naval industries are very strong in the international markets such as the Middle East, Africa, Asia, and Latin America. The defense budgets of these regions are steadily rising and they do not possess a comprehensive naval industry. Export markets nowadays account for 42 percent of the European naval order book value. Indeed, as underlined in Figure 1, exports of the European naval shipbuilding industry have fluctuated widely since the end of the cold war. The European industry cannot rely on exports to sustainably balance domestic orders. ${ }^{13}$

Due to innovative platforms and the relative weakness of non-European competitors, the European industry has been able to obtain a large share of open international tenders and one would expect this to be true for at least the near future as 
well. According to PRNewswire, a consultancy, the global submarine market will grow to USD36.3 billion in 2026 from USD22.8 billion in 2016, with large markets in Asia Pacific (32 percent), Europe (24 percent), and the Middle East, Latin America, and Africa (7 percent, respectively). Similarly, according to Business Wire, the global naval surface vessels market is valued at USD50.3 billion by 2026 as compared to USD6.3 billion in $2016 .^{14}$

Nevertheless, reliance on exports could be dangerous. The long-term importance of international markets is not guaranteed and export dependence can create biases in the development of new platforms when their specifications are overly determined by export requirements. For instance, France launched the Belh@rra intermediary frigate program, which aims at conquering international sales thanks to its modularity and flexibility. Many recent projects are structured on the same idea, and one has to wonder whether such export-driven naval programs will continue to satisfy the domestic needs for strategic autonomy. ${ }^{15}$

Even if an export strategy is successful for the time being, many importing countries expect to develop their own naval industry. As intra-European competition is fierce on the export markets, companies (and countries) may be forced to accept large transfers of technological and production know-how. Therefore, the facilitator of today's viability contains seeds of potential doom once importing countries achieve some degree of self-sufficiency.

\section{Conclusion}

Despite relatively low levels of activity, Europe's main naval shipyards have survived since the 1990s. They did this without entering into true Europe-wide consolidation even as sectoral redundancies have been clear for decades. Even if national naval shipyards benefit today from the reinvestment cycle of their domestic customers, the future of the industry does not necessarily look rosy. For now, the companies can survive with low production levels and the in-service support of fleets. However, low turnover and profitability do not provide enough resources to invest in tomorrow's technologies and systems.

Neither companies nor states can be satisfied by today's organization of Europe's naval sector, sensitive as it is to budgetary and export "bumps". Yet Europe-wide consolidation is unlikely, especially if one looks for the same sort of merger and acquisition process that the aeronautics and space sectors achieved in the 1990s or the more recent consolidation in land systems. The European naval sector needs to invest in both $\mathrm{R} \& \mathrm{D}$ and industrial capacities in critical technologies to maintain its competitive and technological lead and also to ensure the required level of operational superiority. It seems unlikely that European countries each can realize such investment alone. As cooperative programs appear difficult to launch and as there is a limited sharing of technologies and production, the European Defense Action Plan could constitute a means to develop top-down cooperation among stakeholders in the naval industry. ${ }^{16}$

In November 2016, the European Commission proposed a European Defence Action Plan (EDAP) to support its member states' more efficient spending on joint defense capabilities. EDAP aims to set up a European Defence Fund to support joint investment in research and development of defense equipment and technologies. After a three-year Preparatory Action, the Commission intends to propose "a research window" through a defense research program, funded at EUR500 million per year as from 2020. Additionally, a "capability window" would act as a financial tool allowing participating member states to jointly purchase certain assets to reduce their costs, which should be able to mobilize about EUR5 billion per year. Both mechanisms are ideal tools to promote deeper cooperation among European naval shipbuilders on future capabilities and, one hopes, to the consolidation of this defense sector at the European level. ${ }^{17}$

The overview provided in this article of the transformations experienced by Europe's naval industry shows that a European consolidation was not the only solution approach to sustain fragmented production. A domestically-centered approach does constitute an alternative way but it appears insufficient to guarantee the industry's long-term survival. As European consolidation seems unlikely, one wonders what possible alternative moves could maintain a balance between domestic dynamics and true strategic autonomy. Here convergence with civilian shipyards could be revisited. While an initial round of diversification appeared unsuccessful, some naval companies focused on specialized ships like cruise ships or yachts. Fincantieri, of Italy, is a successful example of this strategy. It may appear surprising, but these civilian market segments share many features with military naval systems, and naval shipyards can leverage competencies to design and produce complex, customized products.

Diversification in the high-end segments of merchant shipbuilding (e.g., cruise ships and mega-yachts) and in related maritime activities (e.g., offshore and marine renewable energy) appears quite successful. According to a 2015-2016 study conducted on behalf of the European Defense Agency, "this diversification strategy has created a favourable cross-fertilization between civil and military technologies (dual-use technologies), both at the Prime Contractors and at the Supply-Chain levels, leading to cost-effective designs and solutions." One wonders if one possible future for Europe's 
naval industry may lie in convergence with sectors beyond shipbuilding or even beyond the defense industrial base. ${ }^{18}$

\section{Notes}

1. Strong competitors: ECORYS (2009).

2. In Europe, the aeronautics and space sectors went through successive consolidation waves that resulted in one overly dominant producer of missile systems (MBDA), two major producers of satellites (Airbus and Thales Alenia Space) and two of helicopters (Airbus and Leonardo). To a lesser extent, the land systems sector experienced cross-border consolidation, too. U.S.-based General Dynamics and BAE Systems took over several small players throughout Europe in the early 2000s, and Nexter (France) and KMW (Germany) merged in 2015, followed by Patria (Finland) and Kongsberg (Norway) in 2016.

3. Global market size: Tran (2016).

4. Weis quote: Weis (2009, p. 3). Domecq quote: http://eda.europa.eu/info-hub/press-centre/latest-news/2016/ 10/18/jorge-domecq-at-euronaval-more-cooperation-neededto-develop-the-next-generation-naval-platforms.

5. One writer: de Briganti (2004).

6. See Bellais, Foucault, and Oudot (2014, pp. 28-31).

7. On ThyssenKrupp and Kockums, see Lundmark (2014).

8. Transaction costs and reputation: Williamson (1967).

9. Booming export markets: EDA (2016, p. 20).

10. Life-cycle issues in the naval shipbuilding industry: See de Penanros and Sellin (2003).

11. Competition from East Asia: Smit (2003, p. 48). U.K. shipyards: Goudie (2003). Italy: Brunelli (2003).

12. Tran (2015).

13. Book value: EDA (2016, p. 20).

14. Submarine market: http://www.prnewswire.com/newsreleases/the-global-submarine-market-2016-2026-30033842 5.html. Surface vessels market: http://www.businesswire.com/ news/home/20161 104005930/en/Global-Naval-Vessels-Surf ace-Combatants-Related-MRO.

15. Belh@rra: Cabirol (2016).

16. On aeronautics, land, and space systems, see the other symposium articles in his issue.

17. European Commission: Press release 30 November 2016. http://europa.eu/rapid/press-release_IP-16-4088_en.htm.

18. Quote: EDA (2016, p. 20).

\section{References}

Bellais, R., M. Foucault, and J.M. Oudot. 2014. Economie de la défense. Paris: La Découverte.

Brunelli M. 2003. "L'industrie italienne de construction navale: le cas de Fincantieri," pp. 71-97 in R. de Penanros and T. Sellin, eds. Géopolitique et industries navales, L'épreuve de la globalisation. Paris: CIRPES.
Cabirol, M. 2016. "Pourquoi la France lance la frégate Belh@rra."18 October.http://www.latribune.fr/entreprises -finance/industrie/aeronautique-defense/pourquoi-la-francelance-le-fregate-belh-arra-608783.html [accessed 21 October 2016].

de Briganti, G. 2004. "European Naval Consolidation Still Remote." 28 October. http://www.defense-aerospace.com/ articles-view/feature/5/47870/european-naval-consolidati on-still-remote.html [accessed 15 October 2016].

de Penanros, R. and T. Sellin, eds. 2003. Géopolitique et industries navales, L'épreuve de la globalisation. Paris: CIRPES.

Domecq, J. 2016. "More Cooperation Needed to Develop the Next Generation Naval Platforms." Euronaval Show. Paris: 18 October. http://eda.europa.eu/info-hub/press-centre/ latest-news/2016/10/18/jorge-domecq-at-euronaval-more -cooperation-needed-to-develop-the-next-generation-nav al-platforms [accessed 19 October 2016].

[EDA] European Defence Agency. 2016. "EU Naval Industry in Good Shape but More R\&T Investment Needed, Study Says." European Defence Matters. No. 11 (October), pp. 20-21.

[ECORYS]. ECORYS Research and Consulting. 2009. "Study on the Competitiveness of the European Shipbuilding Industry." Report to the EU Directorate-General Enterprise and Industry, ENTR/06/054. Rotterdam: ECORYS.

Goudie, I. 2003. "Le complexe industriel naval britannique," pp. 61-69 in R. de Penanros and T. Sellin, eds. Géopolitique et industries navales, L'épreuve de la globalisation. Paris: CIRPES.

Lundmark, M. 2014. "Kockums: The Repatriation of the Swedish Underwater Crown Jewel." Défense \& Industries. No. 1, pp. 7-8. Fondation pour la Recherche Stratégique: Paris.

Smit, W.A. 2003. "La construction navale militaire en Europe: caractéristiques et perspectives," pp. 47-60 in R. de Penanros and T. Sellin, eds. Géopolitique et industries navales, L'épreuve de la globalisation. Paris: CIRPES.

Tran, P. 2015. "DCNS, Fincantieri May Team For More Frigate Work." 11 September. http://www.defensenews. com/story/defense/2015/09/11/dcns-fincantieri-mayteam-more-frigate-work/72069368/ [accessed 20 October 2016].

Tran, P. 2016. "Global Naval Sales Estimated at \$40 Billion.” 10 October. http://www.defensenews.com/articles/globalnaval-sales-estimated-at-40-billion [accessed 29 November 2016].

Weis, A. 2009. "Industrial Power-Essential for European Naval Power." Speaking notes to the 6th Meeting of Naval Defence. Paris, 9 December.

Williamson, O. 1967. "The Economics of Defense Contracting: Incentives and Performances," pp. 217-56 in R. McKean, ed. Issues in Defense Economics. National Bureau of Economic Research (NBER). New York: Columbia University Press. 